\title{
COMPETENCE AND CAPACITY-BUILDING REQUIREMENTS IN TRANSPORT AND LOGISTICS MARKET
}

\author{
Darius Bazaras ${ }^{1}$, Kristina Čǐ̌iūnienè ${ }^{2}$, Ramūnas Palšaitis ${ }^{3}$, Igor Kabashkin ${ }^{4}$ \\ ${ }^{1-3}$ Logistics and Transport Management Department, Vilnius Gediminas Technical University, \\ Plytinès 27, LT-10105, Vilnius, Lithuania, \\ E-mails:darius.bazaras@vgtu.lt; kristina.ciziuniene@vgtu.lt; ramunas.palsaitis@vgtu.lt \\ ${ }^{4}$ Transport and Telecommunication Institute \\ Lomonosova iela 1, LV-1019, Riga, Latvia \\ E-mail:kabashkin.i@tsi.lv
}

\begin{abstract}
The article analyses theoretical aspects of the qualitative assessment of logistics and transport specialists' potential, as well as provides research results on competence and capacity-building process in preparation of logistics and transport specialists. The results enabled to identify problematic areas of graduate integration in the labour market and foresee the possible requirements for professional development. In some cases, internal motivation is related to problematic points or negative view from the environment, as well as poor understanding of knowledge benefits in the person's practical life. Training and education is objectively at the meeting point between research, technological and organisational systems. In such conditions the objective of the education on logistics is to offer the customers the best possible service in the field of the transfer of knowledge in harmony with the trend in logistics programme development. The main problems and perspectives of logistics education and training process are discussed in this article.
\end{abstract}

Keywords: logistics competence, education, problems of training process

\section{Introduction}

Companies are trying to score an advantage against their competitors. Managers devote a great amount of time by reflecting on the directions in which their company must develop. They try to identify the tasks which must be realized. Without good, coordinated team work it cannot be realized. Managers must think about how personnel must change its work and how employees must interact. More and more owners or leaders understand that manpower is important, and that it may be sensible to begin to consider how they can assist with the personnel in order to increase their potential. Accepting that personnel are important means in the company, a great attention must be given to learning and training.

Transport and Logistics is one of the key branches of Economics, thus this particular share of the market requires professionals understanding the principles of the free market, theory of modern Economics, business practices, as well as being able to cooperate and communicate with domestic and international partners. In order to achieve these goals, it is necessary to improve one's professional competencies, accept the principles of life-long learning (nationwide, the benefit generates 2 percent of GDP). On the other hand, it is possible to claim, that economic value is generated by the competencies of the specialists. Therefore, it is necessary to develop employment and entrepreneurship-related skills as it ensure economic and social stability. (Ledauskaite, 2010).

\section{Theoretical Aspects of the Qualitative Assessment of Logistics and Transport Specialists' Potential}

The majority of Baltic States and foreign companies have an international aspect to their supply chains which cover Europe and wider markets. Implemented contemporary information technologies guarantee that new products and services receive international exposure much more quickly. This means that logistics companies located in Lithuania are exposed to international competitors more quickly.

Supply chains are constantly changing and the company's management structures must be transformed from time to time. Companies do implement certain organizational changes themselves, and there is an increasing reliance on outsourcing partners. The ability to maximize such relationships will be the source of advantages. 
The use of modern technologies in logistics is becoming more common. Few major technology changes have a significant impact on logistics activities: wide application of intermodal and multimodal cargo transportation, implementation of modern applied information technologies, Electronic Data Interchange (EDI) and Radio Frequency Identification (RFID). Application of e-business, which enables logistics service providers to work more closely on a collaborative basis with other supply chain partners.

It is identified that modern business performance is oriented to the high professional employees. New technologies replace hackwork and more people are moving towards jobs that are adding more value and hence have the capability to be competitively important. The speed of change will be influenced by the capability of employees to absorb new ideas. Currently in Lithuania companies are competing among themselves for the university graduates which have diplomas in transport management and logistics. There is an evidence of increasing emphasis on the development of internal and external relationships.

Competitive advantage will increasingly involve using information, knowledge and manpower. The traditional sources of logistics advantages, such as 7R (Right place, Right time, Right consumer, Right price...) are becoming very visible and its ability to deliver sustainable advantage is limited. Knowledge, information and the way we manage and organize people are invisible, posing greater challenges to competitors who seek to copy.

According to N. Longworth (2000), there are a great number of requirements applicable to specialists in the 21 st century that are linked to basic, necessary skills important to adjust to the labor market. Specialists must be able to plan and implement learning as a condition for lifelong development process, (Jarvis et. al., 2004; Knowles, 1975; Jucevičienè, 2007) since constantly evolving person is the main company's resource in a competitive market. (Ledauskaitè, 2010).

The character of work is specific in Transport/Logistics sector; apart from all necessary skills applicable to managers, there are certain competencies required for this particular occupation: Logistics Business Organization and Information Management; Processing of Orders, Warehouse Operations ${ }^{6}$ Management, Technological Process Management of Logistics Products` Transportation. Additionally, specialists are expected to develop business, establish and administer transport companies, departments, organize activities, prepare and implement projects and plans to improve business of transport services; prepare and arrange documentation required for business relations development; initiate and implement innovations in transport, giving the priority to International transport and Logistics Activity Management, etc. Therefore, contribution of well-trained specialists in the countries 'economy and development has a major impact (Ledauskaitė, Bazaras, 2008; Ledauskaitė, 2010; Barysienė et.al, 2015; Kabashkin, Lotter, 2009).

V. Zuzevičiūtè (2006, p. 89) claims, that objectives of contemporary Higher Education Community encompass the process of promoting life-long learning and improvement of study process, especially emphasizing the skills necessary for career advancement.

In assessing student career competence, it is necessary to ascertain the ways in which it is developed, i.e. to analyze major peculiarities of career education. The term ,training“ in the context of professional qualification and improvement is used very frequently, however, the term itself raises issues, since in Educology literature the terms ,training“, „learning“ and „education“ are used interchangeably. The term „education“ denotes the most general entirety of personality-oriented formative values which later evolve into self-directed learning. Thus, the term itself is broad, whereas the term ,training“is directed towards mastering certain content. The process of training takes place on the basis of the example of particular personal quality or skill. (Laužackas, 2005, p. 70). On the other hand, V. Stanišauskienès (2004, p. 103, 123) argues that training for career - is an ongoing self-directed learning process taking place in all educational subsystems, where competence, necessary for successful career development, is being implemented and acquired.

Rapid development of knowledge and information society provided the prerequisites for distinguishing new training characteristics, which can be described as accelerating changes and the increasing complexity of the issues. Life-long learning becomes a significant condition for person who seeks to be recruited in the competitive labour market and adapt to constantly changing environment as the entire learning activity takes place at any stage of life to develop personal, civic, social and professional knowledge, skills and competencies. Since alterations in diverse spheres of life require corresponding educational changes, education system and the subordinate institutions must obtain new quality in order to be able to prepare individuals to live, work successfully and create in changing society. 
According (Gallacher, Reeve, 2000) if we want to explore questions about non-formal learning in the workplace, from the perspective of the employees, we will draw on the findings of a research project undertaken by Eraut et al (1998), as part of the ESRC funded by the Learning Society Program. Their study focused on the development of knowledge and skills in employment and involved 120 people with different life, job and educational experience. Interviews were conducted to explore what types of knowledge and skills the participants used in their work activities, how they acquired the capacity to do what they did, and what factors had affected their learning process. Their findings are stark, suggesting that formal education and training provided only a small part of what is learned and used at work. Most of the learning described in their interviews was non-formal, neither clearly specified or planned (Eraut et al, 1998). Consequently, they suggest that dominant assumptions underpinning policy for "The Learning Society", stressing the importance of formal provision, need to be balanced by an understanding of the value of informal learning "on-the-job" and the factors which affect it. (Jim Gallacher, Glasgow Caledonian University, Fiona Reeve, Open University).

Non-formal education in Europe is a recognized field of education with the purpose to promote personal development and active citizenship and help solve the issue of people integration into the labor market (Bazaras, Palsaitis, 2006). There are certain differences in the approach of manufacturing and trading enterprises to logistic services. The data shows that enterprises usually evaluate the situation on the market accurately, understand that it is necessary to position themselves in supply chain correctly, ensure the transparency of mutual relations with chain partners and, certainly, pay special attention to improving the quality and assortment of services for customers (Kabashkin, 2007).

\section{Research Results on Competence and Capacity-Building Process in preparation of Logistics and Transport Specialists}

Transport is a significant sector of the Baltic States economies and its importance continues to grow with their becoming a "border" countries of the EU. This is reflected also in national long-term strategic objectives of economic development. The increase in the number of transport companies and their capacity is creating favorable prospects for specialists, who are able to manage the resources in this field. Also, in the public sector, both at the municipal and national level, there is a need for proper coordination, planning and control of transport-related services. The graduates of the program have confirmed that they have not faced any difficulties in finding jobs upon their graduation. Moreover, the employers expressed their satisfaction with the ability of the graduates to integrate quickly into the work environment.

Research Results on Competence and Capacity-Building Process in preparation of Logistics and Transport Specialists (93 respondents, Lithuania, 2015) shown, that upon completion of the studies in higher education institution, one often faces certain difficulties in integrating into labour market. This might be explained by the lack of personal and professional competencies. Research indicated the shortage of features of Transport and Logistics specialists (Fig. 1).

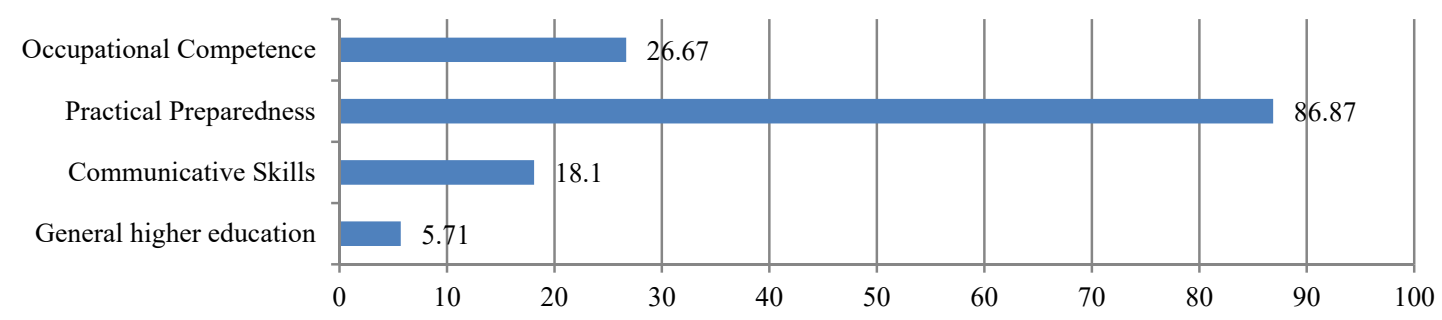

Figure 1. The shortage of features in preparation for professional activities

As can be seen from the picture, respondents are most lacking professional preparedness. However, one must keep in mind, that practical skills are acquired by the means of industrial internships, thus, the development of this feature largely depends on the respondent's effort. Apart from practical preparedness, respondents do lack certain skills (Fig. 2). 


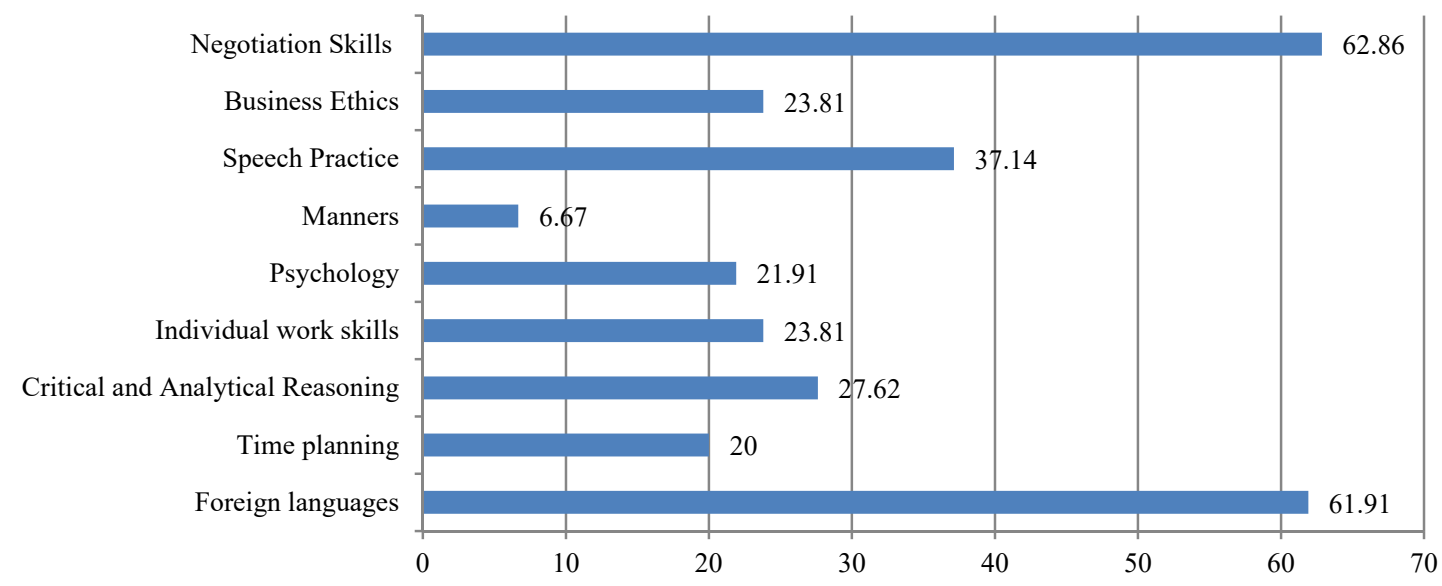

Figure 2. Shortage of Skills of Logistics and Transport Specialists

As the research results indicate, respondents most lack negotiation and foreign language skills, which cause difficulties in communicating with Lithuanian and foreign customers and partners. Considering the fact, that the greater part of work in the Logistics and Transport sector is based on negotiation, it is possible to claim, that the shortage of this skill may negatively impact qualitative and financial results of the company. On the other hand, unformed personal skills and shortage of certain skills poses a great number of shortcomings in Transport and Logistics business (Fig. 3).

Inability to detect, analyze and solve arising problem

Inability to plan one's activities

Poor Awareness of the Companies' Practical Activities

Unformed Personal Skills

Poor Knowledge of Foreign Languages

Inability to work with Computer

Shortage of Theoretical Specialty Knowledge

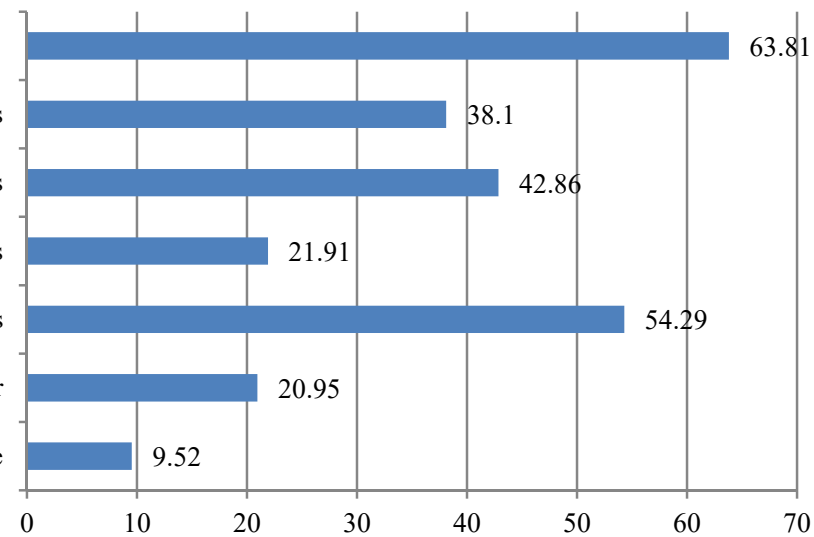

Figure 3. Shortcomings that mostly tend to cause difficulties for Logistics and Transport Specialists in Labor Market

Respondents claimed, that inability to detect, analyse and solve arising problem, as well as poor awareness of the companies' practical activities cause the majority of difficulties. Therefore, the assessment of specialist training criteria becomes an important factor. These factors were assessed on the basis of 10point grading system (where -1 - irrelevant ....10 - very important). On average, all of the criteria are assessed as follows:

- Professional Skills - 8,66 points;

- Foreign languages - 8,29 points;

- Personal Qualities of an Employee - 7,77 points;

- Computer literacy - 7,34 points;

- Obtained Specialty of Specialization- 7,29 points;

- Previous work experience - 6,92 points;

- Completed higher education institution - 6,59 points;

- Science degree - 6,08 points;

- Driving License - 5, 27 points;

- Identical analysis was carried out with the competence assessment of Transport and Logistics Specialists: Communication in Foreign Language - 9,09 points; 
- Communication in Mother Tongue - 8,27 points;

- Ability to learn -8 points;

- Entrepreneurship - 7,74 points;

- Mathematical literacy and basic knowledge of Science and technology- 7,41 points;

- Digital Competence - 7,12 points;

- Cultural Expression - 6,78 points;

- Interpersonal, intercultural and civic competences - 5, 76 points.

As can be seen from the research results, the most important factor for the respondents is communication in mother tongue, which confirms previously analysed indicators and shortcomings.

It must be remembered, that training and building of competencies and skills depend not only on employee, but also on the attitudes of the employer towards additional training and raising ones qualifications. Respondents indicated the most motivating factors: additional financial incentives; perception, that one's work is relevant, awareness of the final results, goals, etc. as well as a sense of responsibility in obtaining results.

\section{Challenges and outlook of the education and training processes of the transport and logistics}

Many consultancy and training firms are organizing miscellaneous, one - two day training courses and during these courses, participants are using much more non - formal education methods or group management methods in comparison with formal education facilities. Participation in these courses is very attractive and pleasurable for the participants, because using of these methods can create comfort and safety atmosphere, but cannot convey systematic knowledge. Commercialization of the Training process is connected with the "syndrome of consumer society". It means that participants of certain training process are thinking that if they pay money, they have become competent automatically or believe, that somebody knows about "super technologies" that could be understood and implemented during lunch-hour. Unfortunately, but this point of view is still present and some consultancy firms which want to avoid conflicts between clients and themselves pay more attention for the "show" but not for deep knowledge.

From another point of view, we cannot reject the role of group's management methods during the training process. If the training course participants are playing the role of "students" and lectors playing role of "lectures" without motivation and internal power - it is the best way to the failure. Motivation is the most important point in the training. Participants must understand that they are not "players for fun", and they can give benefits from knowledge which they get during the training process. These problems related with insufficient teaching methodology, insufficient flexibility, bad understanding of structured knowledge's role in the education process, bad understanding of the knowledge's benefits in the practical life.

The biggest part of these problems can be resolved by complex decisions which can create transformation: data $\rightarrow$ information $\rightarrow$ knowledge. It is means that everybody can collect data, but data are not useful without perceptions. If data are perceived, it becomes information. Unfortunately, many consultancy firms like to stop at this step. Information is enough important, but if person cannot use this information for his/her business or life tasks and create added value - information is fulfilled sketchbook only. Knowledge is information which can be used for the creation of added value in the person, business and personal life and all institutions which have relation to training activities have provide this task (Palšaitis, Bazaras, 2006).

To summarize the insights and research results provided in this article, it is necessary to decide on a certain correlation between competence and training at educational institution level. Recently, a new relevant trend is observed - adapting to current labour market requirements, university degree providing institutions are obliged to form and develop professional and operational competencies, which are generally more preferred by the participants in the market. In this way, universities occupy the position of the establishments, providing vocational training. In accordance with the level of developed competencies, this situation confuses the possible hierarchy within educational institutions. Therefore, it is more accurate to use a broad term ,study philosophy', primarily reflecting the educational institution level, as well as the level of obtained competencies. The concept of educational institution level may comprise the following elements: Assessment of scientific-pedagogical teaching staff by considering academic titles, conducted research and applied research projects in accordance with the requirements of market participants or funded from external sources and EU programs. In determining the level of educational institution, it is important 
to assess the time ratio devoted by the teaching staff to pedagogical-methodical and scientific-investigative activities. In analysing the level of competencies, it is worth noting that all of the mentioned competencies in this article can be divided into two fundamental groups:

- Group A. Competencies developing practical activity skills;

- Group B. Competencies altering individual's reasoning, forming new reasoning schemes, as well as inspiring the search for new technological solutions and its practical applications.

Therefore, it must be determined, that universities and university-level establishments should be focused on the competencies of the Group B. Therefore, the clarity and transparency of educational institutions ' hierarchy are assured, as well as the compliance of developed competencies to its institutional level. The term ,study philosophy' should comprise a holistic approach towards provided competencies, relation of the competence level with institutional level, as well as general orientation to professional education or the formation of a qualitatively new way of thinking.

The EU membership of Baltic States significantly changed the business environment. Business now have new opportunities to enhance logistics, which often requires integrating supply chains internationally with customers, suppliers and logistics providers. It is therefore important for providers of logistics education and training to recognize the needs of the users in order to further develop their services.

As the research results in Latvia indicate (80 respondents, 2014), respondents of manufacturing companies most lack basic logistics skills and transport management (Fig. 4).

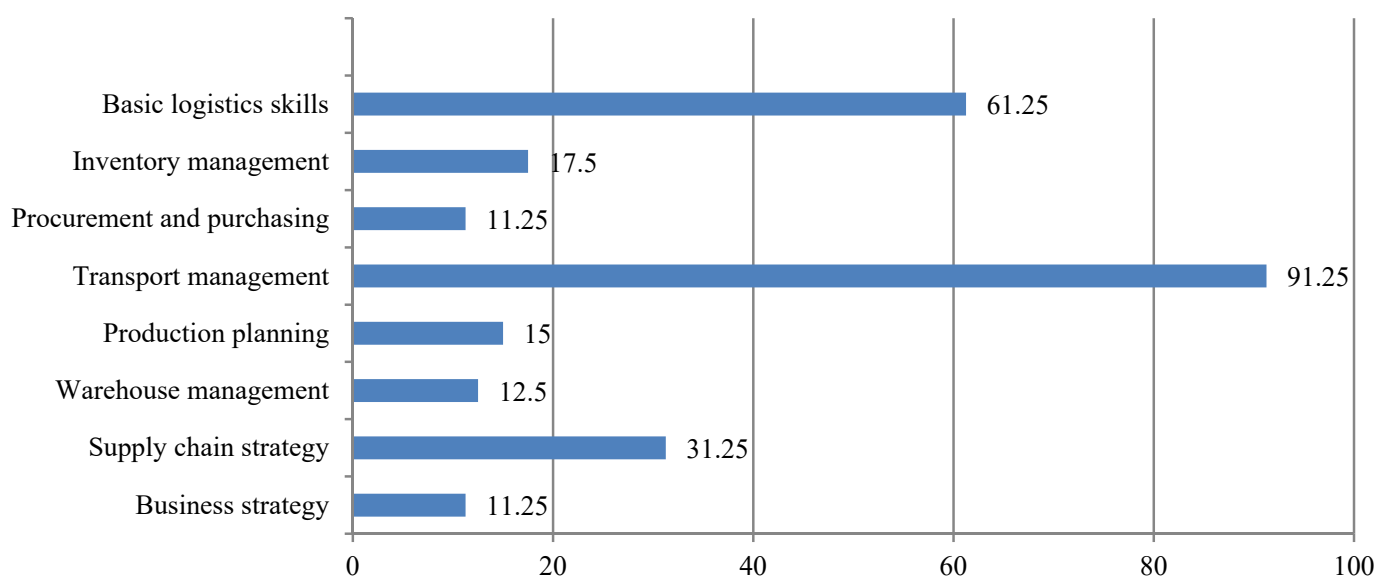

Figure 4. Needs of personnel competence, manufacturing companies

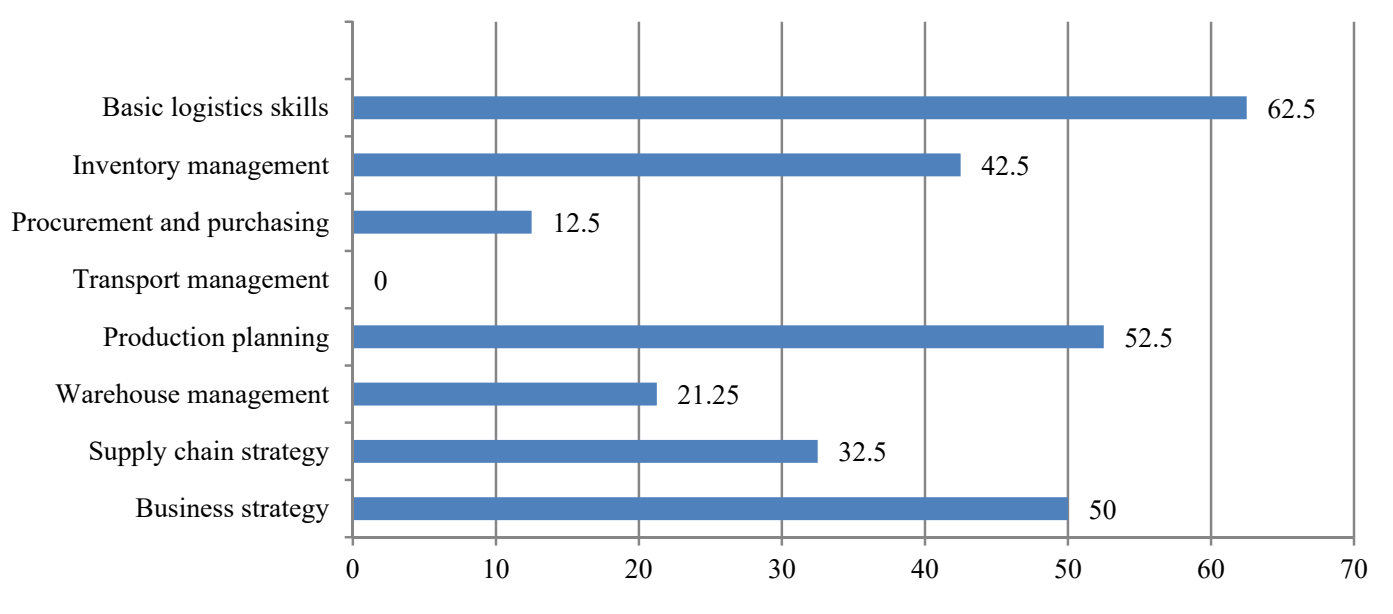

Figure 5. Needs of personnel competence, trading companies

There is a totally different situation in trade. The majority of respondents agree that it is necessary to develop almost all types of logistic competence (Fig.5). If there are no answers about transport 
management, it usually means that companies generally do not have own cargo transport. Transport for them is usually outsourcing.

Partly or indirectly the fact of mentioned above logistic competence necessities can be confirmed by some changing tendencies in Lithuanian and Latvian Education System. The main part of universities and Higher Education Institutes and colleges (state and private) has developed special logistics educational programmes. During last years thousands professionals were prepared in sphere of logistics and transport. Many of them in addition to knowledge of native language know one or two foreign languages.

Training and education is objectively at the meeting point between research, technological and organisational systems. In such conditions the objective of the education on logistics is to offer the customers the best possible service in the field of the transfer of knowledge in harmony with the trend in logistics programme development.

\section{Conclusions}

1. The conducted literature resource analysis shown, that in order to eliminate the obstacles for the graduates of Transport and Logistics to integrate into labour market, it is necessary to develop an integrated intercultural competence and personal qualities.

2. The Research results indicated, that most respondents lack practical skills, which largely depend not only on the higher education institution, but also on the efforts of the respondents. Communication in mother tongue and foreign language becomes no less important issue.

3. The major issues that respondents encounter in the labour market: inability to detect, analyse and solve arising problem, poor knowledge of foreign languages, poor awareness of the Companies' Practical Activities.

4. An additional discussion is meaningful regarding the impact of market requirements on the study system, in particular, university degree providing institutions. In summarizing the institutional levels and competencies, the term ,study philosophy' is to be used. The term ,study philosophy' should comprise a holistic approach towards provided competencies, relation of the competence level with institutional level, as well as general orientation to professional education or the formation of a qualitatively new way of thinking.

5. In the logistics training process we face with psychological influence and life experience, person relation with other persons, commercialization of the training activity and motivation problems relation together. In many cases, commercialization of the training activity connected with desire of commercial firms to avoid conflicts with commercial training course participations. For this reason, firms are trying to use more non-formal education methods for formal education methods, which are more difficult and not attractive. For this reason, the quality of the training process and knowledge become worse.

6. For achieving the quality of the training process, it is necessary to understand the role of transformation from information to knowledge. It is very important to show real benefits of knowledge using at the person's business and/or personal life. It has helped to create more deep motivation for participants and teachers (trainers). Participation and combinations of formal and non-formal education in the training process are welcome.

\section{References}

1. Barysienè, J., Batarlienė, N., Bazaras, D., Čižiūnienė, K., Griškevičienė, D., Griškevičius, A.J., Lazauskas, J., Mačiulis, A., Palšaitis, R., Vasilis-Vasiliauskas, A. \& Vasilienè-Vasiliauskienė, V. 2015. Analysis of the current logistics and transport challenges in the context of the changing environment. Transport. Volume 30, Issue 2, pages 233-241, DOI: 10.3846/16484142.2015.1046403

2. Čepas, P. (2007) Prielaidos ịsidarbinamumo kompetencijos ugdymui, kompetencijos formavimosi laukas. Profesinis rengimas: tyrimai ir realijos, 4, 24-35.

3. Čižiūnienè, K., and Štaraitè, E. (2015) Absolventų integracija ị darbo rinką ir tęstinio mokymosi, kaip investicijų į žmogiškaji kapitalą, poreikis. Respublikinés mokslinès-praktinès konferencijos: Studijos kintančioje verslo aplinkoje, konferencijos, ịvykusios Alytaus kolegijoje 2015 m. balandžio mèn. $24 d$. pranešimų medžiaga, p. 111-115.

4. Gallacher, J., Reeve, F. (2000) "Work-based Leaning: The Implications for Higher Education and for Supporting Informal Learning in the Workplace", Working Papers of the Global Colloquium on Supporting Lifelong Learning, Milton Keynes, UK: Open University Press.

5. Jarvis, P., Holford, J., Griffin, C. (2004) The theory and practice of learning. London. Kogan Page.

6. Jucevičienè, P. (2007) Besimokantis miestas. Monografija. Kauno technologijos universitetas. 
7. Kabashkin, I. (2007) Regional Logistics \& ICT Profile. Baltic Regional report 54:2007. Turku School of Economics, Turku, 167 p. DOI: 10.13140/RG.2.1.4554.6003

8. Kabashkin, I., Lotter, H-J. (2009) Common Virtual Environment in the European Transport Training. Transport and Telecommunication, Vol. 10, No 2, 2009, pp. 10-15. ISSN 1407-6160.

9. Kardelis, K. (2002) Moksliniu tyrimu metodologija ir metodai. Leidykla JUDEX. Kaunas.

10. Knowles, M. S. (1975) Self-directed learning. Cambridge: Prentice Hall Regents.

11. Kučinskienè, R. (2003) Ugdymo karjerai metodologija. Klaipėda: Klaipėdos universiteto leidykla.

12. Laužackas, R. (2005) Profesinio rengimo terminu aiškinamasis žodynas. Kaunas: Vytauto didžiojo universiteto leidykla.

13. Laužackas, R. (2005). Profesinio rengimo metodologija. Kaunas: Vytauto didžiojo universiteto leidykla.

14. Ledauskaite, K.; Bazaras, D. Actual attitudes of demands for specialists in transport sector. Transport and Telecommunication, Vol. 9, no. 1 (2008), p. 29-33.ISSN 1407-6160.

15. Ledauskaitè, K. (2010). Transporto sektoriaus žmogiškujų ištekliu potencialo ekonominis vertinimas. Disertacija. Vilnius: Technika.

16. Lepaitè, D. (2003) Kompetencijų plètojančiu studiju programu lygio nustatymo metodologija. Kaunas: Technologija.

17. Longworth, N. (2000). Making lifelong learning work: learning cities for a learning century. London: Kogan Page.

18. Palšaitis, R.; Bazaras, D. (2006) Prospective of Logistics Training in Lithuania. Transport and Telecommunication, 7(2), 390-397. ISSN 1407-6160. Riga.

19. Paulauskaitė, N.; Vanagas, P. (1998) Organizacijos kultūros tyrimas igyvendinant visuotinès kokybès vadyba. Kaunas: Technologija.

20. Petkevičiūtè, N. (2006) Karjeros valdymas: asmenine, individualioji, perspektyva. Kaunas: Vytauto didžiojo universiteto leidykla.

21. Rosinaitè, V. (2009) Studijų karjeros kompetencijų ugdymas: empirinis efektyvumo sąlygų įvertinimas. Acta Paedagigica Vilnensia. Mokslo darbai, 22, 76-87.

22. Stanišauskienè, V. (2004) Rengimosi karjerai proceso socioedukaciniai pagrindai. Kaunas: Technologija.

23. Zuzevičiūtè, V. (2006) Mokymosi universitete strategijos - praktika ir problemos. Pedagogika, 81, 89-95. 